\title{
PENERAPAN BAHAN AJAR BERBASIS INKUIRI TERBIMBING TERHADAP PEMAHAMAN KONSEP BIOLOGI SISWA SMP DI BANJARMASIN BARAT
}

\author{
Saidatun Ni'mah \\ Program Studi Pendidikan Biologi STKIP PGRI Banjarmasin, \\ Email: nimahsaidatun@gmail.com \\ Almira Ulimaz \\ Program Studi Pendidikan Biologi STKIP PGRI Banjarmasin, \\ Email: almiraulimaz2521988@gmail.com \\ Nana Citrawati Lestari \\ Program Studi Pendidikan Biologi STKIP PGRI Banjarmasin, \\ Email: nanacitra7@gmail.com
}

\begin{abstract}
Abstrak
Penelitian ini bertujuan untuk mengetahui pengaruh penerapan bahan ajar berbasis inkuiri terbimbing terhadap pemahaman konsep pada pembelajaran Biologi siswa SMP di Kecamatan Banjarmasin Barat. Penelitian ini menggunakan jenis penelitian quasi experiment dengan rancangan The Nonequivalent Pretes-Postes Control Group Design Populasi dalam penelitian ini adalah siswa SMP Kelas VII yang ada di Kecamatan Banjarmasin Barat. Penentuan sampel menggunakan random sampling. Sampel diuji kesetaraan berdasarkan data raport kelas VII semester satu mata pelajaran IPA. Berdasarkan hasil perhitungan diketahui sampel yang dijadikan penelitian ada dua yaitu SMPN 25 Banjarmasin kelas VIIC sebagai kelas eksperimen dan SMPN 33 Banjarmasin Kelas VIIC sebagai kelas kontrol. Teknik pengumpulan data menggunakan pretes dan postes. Analisis data dilakukan dengan teknik statistik deskriptif untuk mendeskripsikan data dari variabel penelitian. Pengujian hipotesis dilakukan dengan teknik analisis varian One Way Anova yang dibantu oleh program SPSS versi 16 for Windows. Taraf signifikansi dalam pengujian hipotesis adalah $0,05(\mathrm{p} \leq 0,05)$. Sebelum analisis varians, dilakukan uji asumsi yaitu (1) uji normalitas data dan (2) uji homogenitas varian. Kesimpulan dari penelitian terdapat pengaruh penerapan bahan ajar berbasis inkuiri terbimbing terhadap pemahaman konsep pada pembelajaran Biologi siswa SMP di Kecamatan Banjarmasin Barat karena $\mathrm{p}=0,002<\alpha=0,05$.
\end{abstract}

Kata kunci: bahan ajar, inkuiri terbimbing, pemahaman konsep

\begin{abstract}
This study aims to determine the effect of the application of guided inquiry-based teaching materials on the understanding of concepts in Biology Learning of Middle School Students in West Banjarmasin District. The type of this research is a quasiexperiment involving treatment groups and control groups. The research design of the quasi experiment used was The Nonequivalent Pretest-Postest Control Group Design. The population in this study was Grade VII junior high school students in
\end{abstract}


West Banjarmasin District. Determination of samples using random sampling. The research sample was SMPN 25 Banjarmasin class VIIC as an experimental class and SMP 33 Banjarmasin class VIIC as a control class. The experimental class is facilitated with a guided inquiry model and control class using conventional learning. Data collection techniques using pretest and posttest. Data analysis was carried out using descriptive statistical techniques to describe data from the research variables. Hypothesis testing was carried out with One Way Anova variant analysis technique which was assisted by SPSS version 16 for Windows. The significance level in testing the hypothesis is $0.05(p \leq 0.05)$. Before the analysis of variance, the assumption was tested, namely (1) data normality test and (2) variant homogeneity test. The conclusion of the study is that there is an effect of the application of guided inquiry-based teaching materials on the understanding of concepts in Biology Learning of Junior High School Students in West Banjarmasin District because $p=0.002<\alpha=0.05$.

Keywords: teaching materials, guided inquiry, conceptual understanding

\section{PENDAHULUAN}

Pendidikan merupakan suatu proses interaksi manusia dengan lingkungannya yang berlangsung secara sadar dan terencana dalam rangka mengembangkan segala potensinya, baik jasmani (kesehatan fisik) dan ruhani (pikir, rasa, karsa, karya, cipta, budi nurani) yang menimbulkan perubahan positif dan kemajuan, baik kognitif, afektif, maupun psikomotorik yang berlangsung secara terus-menerus guna mencapai tujuan hidupnya. Pendidikan bisa dipahami sebagai proses dan hasil (Ahmadi, 2015). Tujuan pendidikan pada umumnya menyediakan lingkungan yang memungkinkan anak didik untuk mengembangkan bakat dan kemampuan secara optimal sehingga ia dapat mewujudkan dirinya dan berfungsi sepenuhnya sesuai dengan kebutuhan pribadi dan kebutuhan masyarakat (K. A. Astiti, 2013).

Proses pendidikan terjadi apabila antar komponen pendidikan yang ada saling berhubungan secara fungsional dalam suatu kesatuan yang terpadu. Ibarat sebuah kendaraan yang sedang dikendarai akan dapat berjalan dengan baik apabila kondisi kendaraan, pengemudi, dan jalan yang dilalui dalam keadaan baik. Komponen pendidikan yang saling berhubungan secara fungsional dalam suatu kesatuan yang terpadu maka akan didapat hasil pendidikan yang baik.

Keberhasilan suatu pembelajaran dipengaruhi oleh pemilihan model, strategi, dan metode pembelajaran yang dipilih oleh guru yang nantinya dibelajarkan di dalam 
kelas. Hasil wawancara dengan guru IPA SMP di Banjarmasin menunjukkan bahwa hasil belajar siswa masih belum memuaskan. Guru lebih dominan memberikan dan mengajukan masalah sehingga siswa memberikan jawaban tunggal tanpa interaksi lebih lanjut serta masih siswa yang pasif dalam pembelajaran. Selain itu, guru jarang menerapkan model pembelajaran berbasis inkuiri karena kurangnya bahan ajar yang mendukung kegiatan inkuiri.

Pembelajaran tersebut berpeluang menjadikan kondisi pembelajaran yang hanya didominasi guru, monoton, tidak sesuai materi serta karakteristik siswa sehingga berpengaruh terhadap proses pembelajaran dan hasil pembelajaran. Pembelajaran monoton yang dimaksud adalah pembelajaran yang hanya didominasi ceramah oleh guru. Pembelajaran yang demikian akan berdampak pada pelaksanaan pembelajaran dan hasil pembelajaran. Siswa dengan latar belakang dari berbagai daerah dan kebiasaan belajar yang bervariasi juga ikut mempengaruhi proses pembelajaran.

Merancang kegiatan belajar siswa diperlukan guna mengetahui tingkat kemampuan siswa (Jihad, 2013). Guru juga diharuskan menciptakan dan menerapakan berbagai bentuk kegiatan di kelas sehingga secara optimal siswa dapat mengembangkan kemampuan yang ada dalam dirinya. Salah satunya dengan menerapkan bahan ajar yang disusun sesuai dengan karakteristik materi dan siswa. Keberadaan bahan ajar merupakan komponen yang sangat penting dalam suatu proses pembelajaran di kelas karena dapat membantu siswa untuk belajar dan memahami suatu materi.

Bahan ajar merupakan informasi, alat dan teks tertulis maupun tidak tertulis yang tersusun secara sistematis, digunakan untuk membantu tenaga pendidik dalam melaksanakan kegiatan belajar mengajar sehingga tercipta lingkungan/suasana yang memungkinkan peserta didik untuk belajar (Triyono M B, 2009). Seperangkat materi yang disusun secara sistematis baik tertulis maupun tidak tertulis sehingga tercipta suasana yang memungkinkan subjek ajar untuk belajar (Kusdiyanti, 2011). Segala bahan baik informasi, alat maupun teks yang disusun secara sistematis yang digunakan dalam proses pembelajaran dengan tujuan perencanaan dan penelaahan implementasi pembelajaran (Prastowo, 2012).

Bahan ajar berdasarkan teknologi yang digunakan terdiri dari empat kategori, yaitu bahan ajar cetak, bahan ajar dengar (audio), bahan ajar pandang dengar (audio visual), dan bahan ajar multimedia interaktif (interactive teaching material) (Depdiknas, 
2008). Dalam penelitian ini, bahan ajar yang digunakan berupa bahan ajar cetak. Bahan ajar cetak berupa handout, buku, modul, poster, brosur, lembar kerja, wallchart, foto/gambar, dan leaflet. Bahan ajar cetak yang dipilih adalah lembar kerja siswa (LKS). LKS merupakan informasi dan instruksi untuk mengerjakan suatu kegiatan belajar seperti mengerjakan tugas atau latihan yang disajikan dalam bentuk lembaranlembaran (Ernawati dkk, 2017).

Pengembangan bahan ajar yang bahan ajar disusun mengikuti langkah-langkah model pembelajaran inkuiri. Model pembelajaran inkuiri dianggap cocok untuk diterapkan di kelas karena sesuai dengan kurikulum yang berlaku saat ini yakni kurikulum 2013 yang menuntut pembelajaran dilakukan secara scientific approach. Menurut Apriliyana, (2012) menyebutkan bahwa pelaksanaan pembelajaran Biologi dapat dilaksanakan dengan inkuiri ilmiah. Menurut Rusydiyah, (2016) juga berpendapat bahwa dengan pembelajaran inkuiri dapat memberikan kesempatan siswa untuk belajar sesuai dengan gaya belajarnya.

Jenis inkuiri yang dipilih adalah inkuiri terbimbing. Hal ini sejalan dengan hasil penelitian yang dilakukan oleh Setiawan, (2013) menyebutkan bahwa siswa dapat terlibat aktif dalam proses pembelajaran jika menggunakan pembelajaran inkuiri terbimbing Pembelajaran inkuiri terbimbing juga membantu siswa dalam mengintegrasikan pengetahuan yang telah mereka ketahui dan pahami sebelumnya dengan kegiatan yang mereka lakukan di laboratorium (Mustachfidoh, 2013). Pembelajaran inkuiri terbimbing juga membantu siswa dalam mengembangkan pengetahuan, keterampilan, bertanya dan mencari jawaban berdasarkan rasa ketertarikan dan keingintahuannya (Jihad, 2013).

Tujuan penelitian ini untuk mengetahui pengaruh penerapan bahan ajar berbasis inkuiri terbimbing terhadap pemahaman konsep pada Pembelajaran Biologi Siswa SMP di Kecamatan Banjarmasin Barat. Tujuan khusus dalam penelitian ini adalah untuk menguji signifikansi hasil belajar kognitif produk.

\section{METODOLOGI PENELITIAN}

Jenis penelitian ini menggunakan quasi experiment yang melibatkan kelompok perlakuan dan kelompok kontrol. Ragam rancangan penelitian dari kuasi eksperimen yang digunakan adalah The Nonequivalent Pretes-Postes Control Group Design. Kelompok perlakuan atau kelompok eksperimen dalam penelitian ini adalah 
menggunakan model pembelajaran inkuiri terbimbing dan kelompok kontrol menggunakan pembelajaran konvensional.

Populasi penelitian adalah siswa SMP Kelas VII di Kecamatan Banjarmasin Barat. Penentuan sampel menggunakan random sampling. Sampel akan diuji kesetaraan berdasarkan data raport kelas VII semester satu mata pelajaran IPA. Berdasarkan hasil perhitungan uji kesetaraan, ternyata SMP Negeri 25 Banjarmasin kelas VIIC sebagai kelas eksperimen yang terdiri dari 29 siswa dan SMP Negeri 33 Banjarmasin Kelas VIIC sebagai kelas kontrol yang terdiri dari 30 siswa.

Prosedur pengumpulan data diperoleh dari hasil tes belajar IPA dan nilai LKS pada materi pencemaran lingkungan. Instrumen yang digunakan adalah tes tertulis dengan tujuan untuk mengukur pemahaman siswa. Tes yang dikembangkan dalam penelitian ini berupa soal pilihan ganda dan esai yang mengacu pada materi pencemaran lingkungan. Pretes dilaksanakan pada kelas eksperimen dan kelas kontrol yang bertujuan untuk mengetahui pemahaman konsep awal siswa. Selanjutnya pembelajaran yang menerapkan bahan ajar berbasis inkuiri terbimbing diterapkan di kelas eksperimen dan di kelas kontrol menerapkan pembelajaran konvensional. Pelaksanaan postes dilakukan di akhir pembelajaran dengan tujuan untuk mengetahui pemahaman konsep siswa setelah penerapan bahan ajar berbasis inkuiri terbimbing dan pembelajaran konvensional.

Teknik analisis data yang digunakan adalah teknik statistik deskriptif dengan maksud menjelaskan data dari variabel penelitian. Pengujian hipotesis dilakukan dengan teknik analisis varian One Way Anova menggunakan aplikasi SPSS versi 16 for Windows. Dalam uji hipotesis menggunakan taraf signifikasi yaitu 0,05 ( $\mathrm{p} \leq 0,05)$. Uji asumsi berupa uji normalitas data dan uji homogenitas varian dilakukan sebelum tahap analisis varians.

\section{HASIL PENELITIAN DAN PEMBAHASAN}

\section{Hasil Penelitian}

Berdasarkan hasil penelitian yang telah dilakukan, diperoleh nilai pretes dan postes yang telah disesuaikan dengan rubrik penilaian hasil belajar kognitif sebagai acuan penilain. Data yang dimaksud tersebut terdapat pada Tabel 1 berikut:

Tabel 1. Deskripsi Statistik Pemahaman Siswa (Hasil Belajar Kognitif) 


\begin{tabular}{|c|c|c|c|c|c|c|c|c|c|}
\hline & & \multirow[b]{2}{*}{$\mathbf{N}$} & \multirow[b]{2}{*}{ Mean } & \multirow[b]{2}{*}{$\begin{array}{c}\text { Std. } \\
\text { Deviation }\end{array}$} & \multirow[b]{2}{*}{$\begin{array}{l}\text { Std. } \\
\text { Error }\end{array}$} & \multicolumn{2}{|c|}{$\begin{array}{l}\text { 95\% Confidence } \\
\text { Interval for Mean }\end{array}$} & \multirow[b]{2}{*}{ Minimum } & \multirow[b]{2}{*}{ Maximum } \\
\hline & & & & & & $\begin{array}{l}\text { Lower } \\
\text { Bound }\end{array}$ & $\begin{array}{l}\text { Upper } \\
\text { Bound }\end{array}$ & & \\
\hline \multirow[t]{3}{*}{ Pretes } & 1 & 30 & 56.57 & 11.982 & 2.188 & 52.09 & 61.04 & 22 & 81 \\
\hline & 2 & 29 & 49.17 & 11.723 & 2.177 & 44.71 & 53.63 & 32 & 69 \\
\hline & Total & 59 & 52.93 & 12.330 & 1.605 & 49.72 & 56.15 & 22 & 81 \\
\hline \multirow[t]{3}{*}{ Postes } & 1 & 30 & 54.70 & 18.107 & 3.306 & 47.94 & 61.46 & 0 & 84 \\
\hline & 2 & 29 & 68.28 & 12.889 & 2.393 & 63.37 & 73.18 & 40 & 86 \\
\hline & Total & 59 & 61.37 & 17.059 & 2.221 & 56.93 & 65.82 & 0 & 86 \\
\hline
\end{tabular}

Berdasarkan Tabel 1 diketahui bahwa nilai rata-rata pretes kelas kontrol sebesar 56,57 dan menurun pada postes menjadi 54,70. Pada kelas eksperimen, nilai pretes diperoleh rata-rata sebesar 49,17 dan meningkat pada postes sebesar 68,28 . Selanjutnya juga dilakukan uji normalitas yang bertujuan untuk mengetahui data berdistribusi normal atau tidak berdasarkan data yang telah diperoleh menggunakan uji One-Sample Kolmogorov-Smirnov. Data yang dimaksud tersebut terdapat pada Tabel 2 berikut:

Tabel 2 Deskripsi Data Uji Normalitas

\begin{tabular}{|c|c|c|c|c|}
\hline & Null Hypothesis & Test & Sig. & Decision \\
\hline 1 & $\begin{array}{l}\text { The categories defined by Model } \\
=1 \text { and } 2 \text { occur with probabilities } 0.5 \text { and } 0.5\end{array}$ & $\begin{array}{l}\text { One-Sample Binomial } \\
\text { Test }\end{array}$ & $.200^{1,2}$ & $\begin{array}{l}\text { Retain the null } \\
\text { hypothesis }\end{array}$ \\
\hline 2 & $\begin{array}{l}\text { The distribution of Pretes is normal with } \\
\text { mean } 53 \text { and standard deviation } 12.330\end{array}$ & $\begin{array}{c}\text { One-Sample Kolmogorov- } \\
\text { Smirnov Test }\end{array}$ & $.200^{1,2}$ & $\begin{array}{l}\text { Retain the null } \\
\text { hypothesis }\end{array}$ \\
\hline 3 & $\begin{array}{l}\text { The distribution of Postes is normak with } \\
\text { mean } 61 \text { and standard deviation } 17.059\end{array}$ & $\begin{array}{l}\text { One-Sample Kolmogorov- } \\
\text { Smirnov Test }\end{array}$ & $.200^{1,2}$ & $\begin{array}{l}\text { Reject the null } \\
\text { hypothesis }\end{array}$ \\
\hline
\end{tabular}

Keterangan:

Asymptotic sigificances are displayed. The significance level is .05.

${ }^{1}$ Liliefors Corrected

${ }^{2}$ This is a lower bound of the true significance

Dari tabel 2 dapat dikatakan bahwa data pretes berdistribusi normal karena memiliki nilai signifikansi 0,200. Data postes juga berdistribusi normal karena nilai signifikansi yang didapat sebesar 0,200. Uji homogenitas juga dilakukan dengan maksud untuk mengetahui sampel yang diambil berasal dari populasi dengan varian yang homogen atau tidak menggunakan uji Levene's Test. Data dapat dikatakan homogen jika probabilitas $>0,05$ maka $\mathrm{H}_{\mathrm{o}}$ diterima. Apabila probabilitas $<0,05$ maka $\mathrm{H}_{\mathrm{a}}$ ditolak. Data yang dimaksud tersebut terdapat pada Tabel 3 berikut: 
Tabel 3 Deskripsi Data Uji Homogenitas

\begin{tabular}{lllll}
\hline & $\begin{array}{l}\text { Levene } \\
\text { Statistic }\end{array}$ & df1 & df2 & Sig. \\
\hline Pretes & .126 & 1 & 57 & .724 \\
Postes & .059 & 1 & 57 & .808 \\
\hline
\end{tabular}

Berdasarkan Tabel 3 diketahui nilai signifikansi pretes sebesar 0,724 dan nilai signifikansi postes sebesar 0,808. Kedua nilai tersebut $>$ dari 0,05 sehingga dapat dikatakan menerima $\mathrm{H}_{\mathrm{o}}$ dan menolak $\mathrm{H}_{\mathrm{a}}$. Artinya bahwa nilai pada kelas kontrol dan kelas eksperimen tersebut tidak terdapat perbedaan atau dengan kata lain homogenitas telah terpenuhi. Selanjutnya dilakukan uji hipotesis menggunakan uji anova satu jalur. Data yang dimaksud tersebut terdapat pada Tabel 4 berikut:

Tabel 4 Ringkasan Hasil Uji Anova Satu Jalur

\begin{tabular}{llrrrrr}
\hline & & $\begin{array}{c}\text { Sum of } \\
\text { Squares }\end{array}$ & df & Mean Square & \multicolumn{1}{c}{ F } & Sig. \\
\hline Postes & Between & 2717.704 & 1 & 2717.704 & 10.940 & .002 \\
& Groups & 14160.093 & 57 & 248.423 & & \\
& Within Groups & 16877.797 & 58 & & & \\
& Total & & & & & \\
\hline
\end{tabular}

Berdasarkan Tabel 4 diketahui bahwa postes memiliki nilai $F_{\text {hitung }}$ sebesar 10,940 dengan nilai signifikansi sebesar 0,002 atau kurang dari 0,005. Nilai signifikansi yang diperoleh sebesar 0,002 sehingga dapat dikatakan terdapat pengaruh yang signifikan pada penerapan bahan ajar berbasis inkuiri terbimbing terhadap pemahaman siswa berdasarkan hasil belajar kognitif siswa.

Penggunaan bahan ajar berupa LKS bertujuan sebagai sumber belajar yang membantu siswa menambah informasi mengenai konsep yang dipelajari. LKS yang digunakan mengikuti langkah-langkah model pembelajaran inkuiri terbimbing dan diberikan kepada siswa secara berkelompok pada setiap kali pertemuan selama empat kali pertemuan. Data yang dimaksud terdapat pada Tabel 5 berikut:

Tabel 5. Ringkasan Hasil Lembar Kerja Siswa

\begin{tabular}{cccccc}
\hline Pertemuan & Kelompok & Nilai LKS & Pertemuan & Kelompok & Nilai LKS \\
\hline \multirow{2}{*}{1} & I & 57 & & I & 67 \\
& II & 73 & & II & 82 \\
& III & 58 & & III & 78 \\
& IV & 73 & 3 & IV & 87 \\
& V & 52 & & V & 77 \\
& VI & 73 & & VI & 60 \\
& VII & 62 & & VII & 88 \\
& VIII & 67 & & VIII & 82 \\
\hline
\end{tabular}




\begin{tabular}{ccccc} 
& Rata-rata & $\mathbf{6 4 , 3 7}$ & Rata-rata & $\mathbf{7 7 , 6 2}$ \\
\hline & I & 67 & I & 87 \\
II & 67 & II & 87 \\
III & 83 & III & 93 \\
IV & 83 & IV & 87 \\
V & 67 & V & 82 \\
VI & 73 & 4 & VI & 80 \\
VII & 60 & & VII & 87 \\
VIII & 77 & VIII & 87 \\
& Rata-rata & $\mathbf{7 2 , 1 2}$ & Rata-rata & $\mathbf{8 6 , 2 5}$ \\
\hline
\end{tabular}

Berdasarkan Tabel 5 diketahui rata-rata siswa mengerjakan LKS mengalami peningkatan pada seiap pertemuannya. Rata-rata pada pertemuan 1 sebesar 64,37, pertemuan 2 sebesar 72,17, pertemuan 3 sebesar 77,62 dan pertemuan 4 sebesar 86,25.

Pemahaman siswa yang dinilai dalam penelitian ini dilihat dari nilai siswa mengerjakan pretes dan postes yang diberikan oleh guru. Tujuan dari pelaksanaan pretes adalah mengetahui kemampuan awal yang dimiliki siswa terhadap bahan ajaran yang akan dijadikan topik dalam proses pembelajaran. Tujuan dari pelaksanaan postes adalah mengetahui tingkat penguasaan siswa terhadap kompetensi dasar yang telah ditentukan, baik secara individu maupun kelompok (Mulyasa, 2013).

Berdasarkan data pretes menunjukkan nilai rata-rata pada kelas kontrol lebih tinggi dari nilai rata-rata pada kelas eksperimen. Rata-rata pretes kelas kontrol yaitu 56,57 dan rata-rata pretes kelas eksperimen sebesar 49,17. Berdasarkan data tersebut disimpulkan bahwa input kelas kontrol lebih baik dari pada input kelas eksperimen. Meskipun demikian, nilai rata-rata pretes kelas eksperimen dan kelas kontrol terdapat perbedaan, nilai tersebut tidak mempengaruhi terhadap hasil uji homogenitas pretes yang menyatakan kelas tersebut homogen.

Nilai rata-rata hasil postes kelas kontrol lebih rendah dari nilai rata-rata pada kelas eksperimen. Rata-rata postes kelas kontrol yaitu 54,70 dan rata-rata postes kelas kelas eksperimen yaitu 68,28. Perbedaan nilai tersebut dapat disebabkan karena pada kelas eksperimen telah difasilitasi dengan bahan ajar berbasis inkuiri terbimbing. Dalam pembelajaran inkuiri terbimbing membuat siswa terlibat aktif dalam pembelajaran sehingga meningkatkan motivasinya untuk belajar. Hal ini sejalan dengan hasil penelitian (Sakdiah, 2018) yang menyatakan bahwa melalui pembelajaran inkuiri terbimbing siswa diberi kesempatan belajar secara aktif sehingga peran guru tidak lagi dominan. Kekuatan atau keuntungan dari implementasi pembelajaran kooperatif salah satunya adalah dapat meningkatkan prestasi akademis (Hariyanto, 2012). 
Hasil penilaian terhadap LKS yang dikerjakan oleh siswa secara berkelompok menunjukkan hasil yang baik. Dari empat pertemuan yang dilaksanakan, rata-rata penilaian terhadap LKS mengalami peningkatan. Dari nilai rata-rata delapan kelompok diketahui bahwa rata-rata untuk pertemuan 1 sebesar 64,37, pertemuan 2 sebesar 72,17, pertemuan 3 sebesar 77,62 dan pertemuan 4 sebesar 86,25. Adanya peningkatan nilai yang diperoleh siswa menunjukkan bahwa pembelajaran dengan menerapkan bahan ajar berbasis inkuiri terbimbing berjalan dengan baik. Rusman, (2011) menyatakan bahwa pembelajaran kooperatif merupakan suatu model untuk memfasilitasi siswa belajar dalam kelompok-kelompok kecil dengan tingkat kemampuan berbeda. Dalam menyelesaikan tugas kelompok, setiap anggota saling kerjasama dan membantu untuk memahami suatu bahan pembelajaran.

Penggunaan model pembelajaran berbasis inkuiri di kelas yang ditunjukkan melalui penerapan bahan ajar dapat membantu siswa untuk mengintegrasikan konsepkonsep yang telah mereka ketahui sebelumnya dengan peristiwa-peristiwa yang mereka amati di laboratorium. Pembelajaran inkuiri juga dapat mengubah miskonsepsi yang dialami siswa menjadi konsep ilmiah. Belajar dengan menggunakan pembelajaran inkuiri ini diharapkan siswa menjadi lebih kreatif, inovatif, dan belajarnya menjadi lebih bermakna sehingga prestasi belajar biologi dapat ditingkatkan. Hal ini dikarenakan proses belajar inkuiri mengandung proses-proses mental yang lebih tinggi tingkatannya, misalnya merumuskan masalah, merancang percobaan, melakukan eksperimen, mengumpulkan dan menganalisis data, dan menarik kesimpulan (Mustachfidoh, 2013). Siswa terdorong berpikir dan bekerja sesuai dengan inisiatifnya, objektif, jujur, terbuka dan bebas untuk melajar sendiri merupakan bagian dari pembelajaran berbasis inkuiri (Roestiyah, 2012).

\section{SIMPULAN}

Dari hasil penelitian menunjkkan bahwa terdapat pengaruh pada penerapan bahan ajar berbasis inkuiri terbimbing terhadap pemahaman konsep pada Pembelajaran Biologi Siswa SMP di Kecamatan Banjarmasin Barat hal tersebuut berdasarkan pada nilai $\mathrm{p}=0,002<\alpha=0,05$. Rata-rata hasil belajar siswa mengerjakan LKS mengalami peningkatan pada setiap pertemuannya. 


\section{DAFTAR PUSTAKA}

Ahmadi, Rulam. (2015). Pengantar Pendidikan: Asas dan Filsafat Pendidikan. Cetakan Pertama penyunt. Yogyakarta: Ar-Ruzz Media.

Apriliyana, U., Herlina Fitrihidayati, \& Rahardjo. (2012). Pengembangan Perangkat Pembelajaran Berbasis Inkuiri Terbimbing pada Materi Pencemaran Lingkungan dalam Upaya Melatih Keterampilan Berpikir Kritis Siswa Kelas X $\begin{array}{llll}\text { SMA. BioEdu (Online), } & \text { I(3), }\end{array}$ (https://media.neliti.com/media/publications/241792-pengembangan-perangkatpembelajaran-berb-40c4f5eb.pdf, diakses 03 Juni 2017).

Depdiknas. 2008. Panduan Umum Pengembangan Bahan Ajar. Jakarta: Direktorat Jenderal Manajemen Pendidikan Dasar dan Menengah.

Hariyanto \& Warsono. (2012). Pembelajaran Aktif: Teori dan Asesmen. Cetakan Pertama penyunt. Bandung: PT. Remaja Rosdakarya.

Jihad, Asep \& Suyanto. (2013). Menjadi Guru Profesional : Strategi Meningkatkan Kualifikasi dan Kualitas di Era Globalisasi. Cetakan Pertama penyunt. Jakarta: Esensi Erlangga Group.

K. A. Astiti, I. W. Sadia, \& K. Suma. (2013). Pengaruh Model Pembelajaran Inkuiri Hipotetik terhadap Keterampilan Berfikir Kritis dan Keterampilan Proses Sains Siswa Kelas VII SMP Negeri 1 Singaraja. Jurnal Pendidikan dan Pembelajaran IPA Indonesia (Online), III(1), pp. 1-13. (http://oldpasca.undiksha.ac.id/ejournal/index.php/jurnal_ipa/article/view/753, diakses 08 Agustus 2018).

Kusdiyanti, H. (2011). Pelatihan Pengembangan Bahan Ajar Kearsipan Berbasis Potensi Lokal dalam Rangka Program Pemberdayaan Siswa Binaan Labsosdik di SMK se-Malang, Malang: LP3 UM.

Mulyasa, E. (2013). Implementasi Kurikulum Tingkat Satuan Pendidikan: Kemandirian Guru dan Kepala Sekolah. Cetakan Kelima penyunt. Jakarta: Bumi Aksara.

Mustachfidoh, I. B. Jelantik Swasta. \& N. L. P. Manik Widyanti. (2013). Pengaruh Model Pembelajaran Inkuiri Terhadap Prestasi Belajar Biologi ditinjau dari Intelegensi Siswa SMA Negeri 1 Srono. Jurnal Pendidikan dan Pembelajaran IPA Indonesia (Online), III(1), pp. 1-11. (http://oldpasca.undiksha.ac.id/ejournal/index.php/jurnal_ipa/article/view/542, diakses 26 Mei 2018).

Prastowo, Andi. (2012). Panduan Kreatif Membuat Bahan Ajar Inovatif: Menciptakan Metode Pembelajaran yang Menarik dan Menyenangkan. Cetakan Pertama penyunt. Yogyakarta: Diva Press.

Roestiyah. (2012). Strategi Belajar Mengajar. Cetakan kedelapan penyunt. Jakarta: PT. Rineka Cipta.

Rusman. (2011). Model-model Pembelajaran: Mengembangkan Profesionalisme Guru. Cetakan Ketiga penyunt. Jakarta: PT RajaGrafindo Persada. 
Rusydiyah, Evi Fatimatur \& Ali Mudlofir. (2016). Desain Pembelajaran Inovatif: Dari Teori ke Praktik. Cetakan Pertama penyunt. Jakarta: PT. RajaGrafindo Persada.

Sakdiah, Mursal, \& Muhammad Syukri. (2018). Penerapan Model Inkuiri Terbimbing untuk Meningkatkan Pemahaman Konsep dan KPS pada Materi Listrik Dinamis Siswa SMP. Jurnal IPA dan Pembelajaran IPA (Online), II(1), pp. 41-49 (http://www.jurnal.unsyiah.ac.id/JIPI/article/view/10727, diakses 19 September 2018).

Setiawan, B \& Y. Astuti. (2013). Pengembangan Lembar Kerja Siswa (LKS) Berbasis Pendekatan Inkuiri Terbimbing dalam Pembelajaran Kooperatif pada Materi Kalor. Jurnal Pendidikan IPA Indonesia (Online), II(1), pp. 88-92 (https://journal.unnes.ac.id/nju/index.php/jpii/article/view/2515, diakses 02 Maret 2018).

Triyono M B, S. B. T. H. d. W., 2009. Materi Diklat Training of Trainer Calon Tenaga Pengajar/Dosen Lingkungan Badiklat Perhubungan, Magelang: Badan Diklat DEPHUB. 